\title{
Assessment of Site Selection Criteria for Medical Waste during COVID-19 Pandemic
}

\author{
Mehmet Ali Taș ${ }^{1 *}$ \\ 1* Türk-Alman Üniversitesi, Endüstri Mühendisliği Bölümü, İstanbul, Türkiye, (ORCID: 0000-0003-3333-7972), mehmetali.tas@tau.edu.tr
}

(1st International Conference on Applied Engineering and Natural Sciences ICAENS 2021, November 1-3, 2021)

(DOI: 10.31590/ejosat.984857)

ATIF/REFERENCE: Taş, M. A. (2021). Assessment of Site Selection Criteria for Medical Waste during COVID-19 Pandemic. European Journal of Science and Technology, (28), 63-69.

\begin{abstract}
The COVID-19 virus has affected the whole world, causing it to be declared a pandemic. To prevent the spread of the virus, the use of medical products such as masks and disinfectants was encouraged and even mandatory in some places. This situation makes the waste of medical products used a threat to public health. It becomes an important decision where to depot the used medical products before disposal due to the risk of containing the virus. There are many criteria to consider during the selection of a site. This study includes the evaluation of criteria for the selection of pre-disposal temporary landfill site for medicinal products in Turkey. Eight criteria were determined to be used in the selection of these sites. The weights of the criteria were calculated using the fuzzy Pivot Pairwise Relative Criteria Importance Assessment (PIPRECIA) method, which is a multi-criteria decision making method. According to the results, it was concluded that the most important evaluation criterion was distance to residential areas. The results of this study are aimed to contribute to the management of medical waste.
\end{abstract}

\section{COVID-19 Pandemisinde Tıbbi Atıklar için Yer Seçim Kriterlerinin Değerlendirilmesi}

$\ddot{\mathbf{O z}}$

COVID-19 virüsü tüm dünyayı etkilemiş ve pandemi ilan edilmesine neden olmuştur. Virüsün yayılmasını önlemek için maske ve dezenfektan gibi tıbbi ürünlerin kullanımı teşvik edilmiş ve hatta bazı yerlerde zorunlu hale getirilmiştir. Bu durum, kullanılan tıbbi ürünlerin atıklarını halk sağlığı için bir tehdit haline getirmektedir. Virüs içerme riski nedeniyle kullanılmış tıbbi ürünlerin bertarafından önce nerede toplanacağı önemli bir karar haline gelmiş̧tir. Yer seçimi yapılırken göz önünde bulundurulması gereken birçok kriter bulunabilir. $\mathrm{Bu}$ çalışma, Türkiye'de tıbbi ürünler için bertaraf işlemi öncesi geçici toplama yeri seçimindeki kriterlerin değerlendirilmesini içermektedir. Bu yerlerin seçiminde kullanılmak üzere on değerlendirme kriteri belirlenmiştir. Kriterlerin ağırlıkları, bir çok kriterli bir karar verme yöntemi olan bulanık PIPRECIA yöntemi kullanılarak hesaplanmıştır. Elde edilen sonuçlara göre en önemli değerlendirme kriterinin yerleşim alanlarına uzaklık olduğu sonucuna varılmıştır. Bu çalışmanın sonuçlarının tıbbi atık yönetimine katkı sağlaması amaçlanmaktadır.

Anahtar Kelimeler: COVID-19, Çok Kriterli Karar Verme, Bulanık PIPRECIA, Medikal Atık, Yer Seçimi.

\footnotetext{
* Corresponding Author: mehmetali.tas@tau.edu.tr
} 


\section{Introduction}

The COVID-19 virus has spread rapidly all over the world because it can easily be transmitted from person to person (Shereen et al., 2020). Due to its severe consequences, it threatens especially the elderly and people with chronic diseases. In order to be protected from the virus and not be infected, it is recommended by the World Health Organization that people wear personal face coverings (masks) in daily life (WHO, 2021). In addition to many precautions such as washing hands, not touching the face, and self-isolating; personal protective equipment and products also can be used such as alcohol-based sanitizers, gloves, and so on (FDA, 2020). The necessity of changing single-use masks frequently and the plastic bottles of virus-killing products as hand sanitizers make the medical waste a subject to be considered.

The amount of medical waste, which was an average of 40 tons per day in the city of Wuhan (China), increased sixfold in 2020, when the COVID-19 epidemic began, to 240 tons per day (SCMP, 2020). Some researches have emphasized recycling the waste of medical products during COVID-19 period (Crespo et al., 2021). Despite this, the disposal of these products is preferred in terms of public health (Sangkham, 2020). They should be accumulated separately from general recyclables such as plastic, glass, or paper products. Many countries have decided to determine separate bins for medical products and to temporarily landfill the collected products in distanced sites before disposal (Sharma et al., 2020). The problem of the site assessment is challenging and complex, as there are different criteria to be considered. For this purpose, multi-criteria decision making methods (MCDM) can be utilized in COVID-19 cases (Çakır et al., 2021).

MCDM methods are standardized methods that enable decision analysis by evaluating contradictory criteria together. In the literature, there are many studies on site selection and assessment in various application areas with the help of MCDM methods (Shao et al., 2020; Malemnganbi \& Shimray, 2020). Sánchez-Lozano et al. (2013) used MCDM methods, AHP and TOPSIS, in an integrated way, to appraise solar farm sites in Spain. Chen et al. (2014) also used DANP and DEMATEL methods as MCDM methods for solar farm site selection. Żak and Węgliński (2014) selected the best location for the logistics center with the ELECTRE III/IV method. Similarly, Mihajlović et al. (2019) implemented WASPAS and AHP methods in choosing the logistics distribution center location in Serbia. Lin et al. (2020) evaluated alternative locations for the car-sharing station in China using the extended MULTIMOORA method. As a recent example, Boyaci and Şişman (2021) employed Pythagorean fuzzy AHP and TOPSIS as MCDM methods in the analysis of places where a pandemic hospital could be established in a province in Turkey.

More specifically, MCDM methods are also utilized in solving waste site selection problems. Liu et al. (2014) used interval 2-tuple linguistic VIKOR in order to site selection for waste management. Şener et al. (2011) selected the best site for solid waste disposal in a region in Turkey using AHP as an MCDM method. Kahraman et al. (2017) also investigated three alternative locations according to three criteria in the site selection study for solid waste disposal using interval-valued intuitionistic fuzzy EDAS. Rahimi et al. (2020) implemented a methodology including BWM, MULTIMOORA, and GIS in order to select sustainable landfill sites for municipal waste in Iran. As can be noticed, these and other MCDM methods can be employed in combination with fuzzy sets (Taş \& Çakır, 2021; Çakır \& Ulukan, 2021).

Fuzzy set theory was introduced by Zadeh (1965) in order to reflect the uncertainty in the opinions of decision makers (DMs). Combining fuzzy sets and MCDM methods together, decision making can be executed by subjective judgments in an imprecise information environment (Tseng, 2011). Fuzzy AHP (Vahidnia et al., 2009), fuzzy ANP (Isalou et al., 2013), fuzzy TOPSIS (Senvar et al., 2016), fuzzy TODIM (Hanine et al., 2016), fuzzy EDAS (Kahraman et al., 2017), and fuzzy VIKOR (Kutlu Gündoğdu \& Kahraman, 2019) are some of the frequently used fuzzy MCDM methods in order to site appraisal. In addition to these methods, fuzzy PIPRECIA, which is a fuzzy MCDM method, can also be used in site assessment problems.

Stanujkic et al. (2017) introduced PIPRECIA method as an extension of the SWARA method, which was proposed by Keršuliene et al. (2010). The PIPRECIA has major advantages over SWARA, such as being suitable for group decision making (Stević et al., 2018). The method can be benefited as a tool for MCDM. Stević et al. (2018) determined the conditions in the application of barcode technology with SWOT analysis and weighted them using fuzzy PIPRECIA. Blagojević et al. (2020) implemented a methodology in which the weights of the subjective criteria taken into account in the appraisal of railway safety were calculated with fuzzy PIPRECIA and also included DEA and Entropy. Đalić et al. (2020), on the other hand, used the same fuzzy method to determine the weights of the green supplier selection criteria. Vesković et al. (2020) and Tomašević et al. (2020) are also involved in studies using fuzzy PIPRECIA to calculate criteria weights in different application areas.

This study includes determining the importance of the criteria for selecting a site for medical wastes during the COVID-19 pandemic period in Turkey. As a result of the literature review, eight criteria were determined. In the assessment of the criteria, the opinions of four DMs were taken. According to these opinions, the fuzzy PIPRECIA method is used to calculate the weights. The fuzzy PIPRECIA method was preferred because of its structure suitable for group decisions. The aim of the study is to contribute to the solution of site assessment problems for medical wastes.

The rest of this study is structured as: The fuzzy PIPRECIA methodology is given in Section 2. The methodology is implemented in a case study in Section 3. Finally, the study is ended with the conclusion, limitations, and future directions in Section 4.

\section{Methodology}

The fuzzy PIPRECIA method consists of basically two main steps and the steps below them (Stanujkic et al., 2017; Stević et al., 2018).

\section{Step 1. The normal fuzzy PIPRECIA steps}

Step 1. 1. Determining the attributes (criteria) and sorting them by their expected priorities (without classification).

Step 1. 2. Starting with the second-order criterion, each DM assesses the previously sorted $C_{j}$ criteria (Eq. (1)). In Eq. (1), the 
notation $\widetilde{s_{\jmath}^{r}}$ represents for DM's evaluation for criteria. The scales for evaluations are placed in Table 1.

Table 1. The scales for evaluations of the criteria

\begin{tabular}{|c|c|c|c|}
\hline \multicolumn{2}{|c|}{ Scale 0-1 } & \multicolumn{2}{|c|}{ Scale 1-2 } \\
\hline $\begin{array}{c}\text { Linguistic } \\
\text { variables }\end{array}$ & $\begin{array}{c}\text { Fuzzy } \\
\text { number }\end{array}$ & $\begin{array}{c}\text { Linguistic } \\
\text { variables }\end{array}$ & Fuzzy number \\
\hline $\begin{array}{l}\text { Absolutely } \\
\text { less } \\
\text { significance }\end{array}$ & $\begin{array}{c}(2 / 9,1 / 4 \\
2 / 7)\end{array}$ & $\begin{array}{l}\text { Absolutely } \\
\text { more } \\
\text { significance }\end{array}$ & $\begin{array}{c}(8 / 5,19 / 10 \\
39 / 20)\end{array}$ \\
\hline $\begin{array}{l}\text { Dominantly } \\
\text { less } \\
\text { significance }\end{array}$ & $\begin{array}{c}(1 / 4,2 / 7 \\
1 / 3)\end{array}$ & $\begin{array}{l}\text { Dominantly } \\
\text { more } \\
\text { significance }\end{array}$ & $(3 / 2,7 / 4,9 / 5)$ \\
\hline $\begin{array}{l}\text { Much less } \\
\text { significance }\end{array}$ & $\begin{array}{c}(2 / 7,1 / 3 \\
2 / 5)\end{array}$ & $\begin{array}{l}\text { Much more } \\
\text { significance }\end{array}$ & $\begin{array}{c}(7 / 5,8 / 5 \\
33 / 20)\end{array}$ \\
\hline $\begin{array}{l}\text { Really less } \\
\text { significance }\end{array}$ & $\begin{array}{c}(1 / 3,2 / 5 \\
1 / 2)\end{array}$ & $\begin{array}{c}\text { More } \\
\text { significance }\end{array}$ & $\begin{array}{c}(13 / 10,29 / 20, \\
3 / 2)\end{array}$ \\
\hline $\begin{array}{c}\text { Less } \\
\text { significance }\end{array}$ & $\begin{array}{c}(2 / 5,1 / 2 \\
2 / 3)\end{array}$ & $\begin{array}{c}\text { Moderately } \\
\text { more } \\
\text { significance }\end{array}$ & $\begin{array}{c}(6 / 5,13 / 10 \\
27 / 20)\end{array}$ \\
\hline $\begin{array}{c}\text { Moderately } \\
\text { less } \\
\text { significance }\end{array}$ & $(1 / 2,2 / 3,1)$ & $\begin{array}{c}\text { Slightly } \\
\text { more } \\
\text { significance }\end{array}$ & $\begin{array}{c}(11 / 10,23 / 20 \\
6 / 5)\end{array}$ \\
\hline $\begin{array}{l}\text { Weakly less } \\
\text { significance }\end{array}$ & $(2 / 3,1,1)$ & $\begin{array}{c}\text { Almost } \\
\text { equal } \\
\text { significance }\end{array}$ & $(1,1,21 / 20)$ \\
\hline
\end{tabular}

If the criterion has less importance than the previous one, linguistic variables from the $0-1$ scale in Table 1 should be used, and if vice versa, linguistic variables from the 1-2 scale should be used.

$$
\widetilde{s_{J}^{r}}=\left\{\begin{array}{lll}
>\tilde{1} & \text { when } & C_{j}>C_{j-1} \\
=\tilde{1} & \text { when } & C_{j}=C_{j-1} \\
<\tilde{1} & \text { when } & C_{j}<C_{j-1}
\end{array}\right.
$$

Step 1. 3. Obtaining $\widetilde{k_{j}}$ value using Eq. (2):

$$
\widetilde{k_{J}}=\left\{\begin{array}{lll}
\tilde{1} & \text { if } & j=1 \\
\tilde{2} \ominus \widetilde{s_{J}} & \text { if } & j>1
\end{array}\right.
$$

Step 1. 4. Determining fuzzy $\widetilde{q_{j}}$ value with Eq. (7):

$$
\widetilde{q_{J}}=\left\{\begin{array}{lll}
\tilde{1} & \text { if } & j=1 \\
\frac{\widetilde{q_{J-1}}}{\widetilde{k_{J}}} & \text { if } & j>1
\end{array}\right.
$$

Step 1. 5. Calculating the fuzzy relative weight $\widetilde{w_{J}}$ by Eq. (4):

$$
\widetilde{w_{J}}=\frac{\widetilde{q_{J}}}{\sum_{j=1}^{n} \widetilde{q_{J}}}
$$

Step 2. The inverse fuzzy PIPRECIA steps

Step 2. 1. All the operations given in the first main step are repeated from the last criterion to the first for $n$ criteria. The $\widetilde{S_{j}^{r^{\prime}}}$ can be obtained with Eq. (5):

$$
\widetilde{s_{j}^{r^{\prime}}}=\left\{\begin{array}{lll}
>\tilde{1} & \text { when } & C_{j}>C_{j+1} \\
=\tilde{1} & \text { when } & C_{j}=C_{j+1} \\
<\tilde{1} & \text { when } & C_{j}<C_{j+1}
\end{array}\right.
$$

$$
\widetilde{k^{\prime}}=\left\{\begin{array}{lll}
\tilde{1} & \text { if } & j=n \\
\tilde{2} \ominus \widetilde{s_{J}} & \text { if } & j>n
\end{array}\right.
$$

Step 2. 3. Determining fuzzy $\widetilde{q^{\prime}}$, value with Eq. (7):

$$
\widetilde{q^{\prime}}{ }_{J}=\left\{\begin{array}{lll}
\widetilde{1} & \text { if } & j=n \\
\frac{{\widetilde{q^{\prime} j+1}}_{\widetilde{k^{\prime}}}}{} & \text { if } & j>n
\end{array}\right.
$$

Step 2. 4. Calculating the fuzzy relative weight $\widetilde{w^{\prime}}{ }_{j}$ with Eq. (8):

$$
\widetilde{W^{\prime}}{ }_{J}=\frac{{\widetilde{q^{\top}}}_{j}}{\sum_{j=1}^{n}{\widetilde{q^{\prime}}}_{J}}
$$

Step 2. 5. Combining the main steps. The final fuzzy weights of the criteria are obtained by using the arithmetic mean of the calculated fuzzy weights (Eq. (9):

$$
\widetilde{w^{f}}{ }_{J}=\frac{\widetilde{w_{J}}+\widetilde{w^{\prime}}}{2}
$$

Step 2. 6. The fuzzy weights of the criteria are defuzzified using Eq. (10) and the final criteria weights are reached.

$$
w_{j}^{f}=\frac{a+(4 * b)+c}{6}
$$

While applying fuzzy PIPRECIA steps, the rules of arithmetic operations on fuzzy numbers are followed. These operations for two triangular fuzzy numbers $\left(A_{1}=\left(a_{1}, b_{1}, c_{1}\right)\right.$ and $B_{1}=$ $\left.\left(a_{2}, b_{2}, c_{2}\right)\right)$ are shown in Eq. (11)-(14):

$$
\begin{gathered}
A_{1} \oplus B_{1}=\left(a_{1}+a_{2}, b_{1}+b_{2}, c_{1}+c_{2}\right) \\
A_{1} \otimes B_{1}=\left(a_{1} a_{2}, b_{1} b_{2}, c_{1} c_{2}\right) \\
A_{1} \ominus B_{1}=\left(a_{1}-c_{2}, b_{1}-b_{2}, c_{1}-a_{2}\right) \\
\frac{A_{1}}{B_{1}}=\left(\frac{a_{1}}{c_{2}}, \frac{b_{1}}{b_{2}}, \frac{c_{1}}{a_{2}}\right)
\end{gathered}
$$

\section{Case Study}

During the COVID-19 period, the usage of medical products, especially single-use masks, has increased exponentially. Used medical products should be disposed without posing a danger to people. These products should be collected at determined sites before disposal. It is aimed by the managers to manage the waste of products properly. It is planned to transport the wastes to the main disposal centers in cities after the temporary landfills. In addition, it is expected that these waste sites also can be suitable for the disposal process according to the amount of waste.

This case study includes the evaluation of the selection of temporary landfill sites for medical waste in Turkey. The assessment criteria created by the literature review are given in Table 2. The opinions of four DMs (DM1, DM2, DM3, and DM4) were consulted to calculate the weights of the criteria.

Step 2. 2. Obtaining $\widetilde{k^{\prime}}$, value using Eq. (6): 
Table 2. The evaluation criteria

\begin{tabular}{c|c|c}
\hline $\begin{array}{c}\text { Criteria } \\
\text { code }\end{array}$ & Criteria & References \\
\hline$C 1$ & Underground water & $\begin{array}{c}\text { Torkayesh et al. } \\
(2021)\end{array}$ \\
\hline$C 2$ & Accessibility to main roads & Liu et al. (2014) \\
\hline$C 3$ & Capacity & Shi et al. (2019) \\
\hline$C 4$ & Distance to residential areas & $\begin{array}{c}\text { Sharifi \& } \\
\text { Retsios (2004) }\end{array}$ \\
\hline$C 5$ & Potential adjacent land using & Shi et al. (2019) \\
\hline$C 6$ & Distance to forests & $\begin{array}{c}\text { Şener et al. } \\
(2011)\end{array}$ \\
\hline$C 7$ & Slope & $\begin{array}{c}\text { Kahraman et al. } \\
(2017)\end{array}$ \\
\hline$C 8$ & Infrastructure & $\begin{array}{c}\text { Moghaddas \& } \\
\text { Namaghi (2011) }\end{array}$ \\
\hline
\end{tabular}

In order to apply the fuzzy PIPRECIA method, four DMs evaluated the criteria listed from $\mathrm{C} 1$ to $\mathrm{C} 8$ in pairs. The second step of normal fuzzy PIPRECIA (Step 1.2) and the first step of the inverse fuzzy PIPRECIA (Step 2.1) were conducted together.

The importance relationship $\left(\widetilde{s_{f}^{r}}\right)$ of all consecutive criteria from $\mathrm{C} 1$ to $\mathrm{C} 8$ according to Eq. (1) in Step 1.2 was assessed by each DM starting from the second row. Linguistic variables in Table 1 and their fuzzy number equivalents were used for the evaluation scale.

For example, the criterion $\mathrm{C} 4$ is less important than for $\mathrm{C} 3$ for DM2 $\left(\widetilde{s_{I}^{2}}\right)$. For this reason, DM selected an assessment from the $0-1$ scale in Table 1 and stated that it has "moderately less significance". On the contrary, DMs also compared the criteria from $\mathrm{C} 8$ to $\mathrm{C} 1$ pairwise and again selected the appropriate linguistic variables from Table 1 (Step 2. 1). The assessments that include the fuzzy number equivalents $\left(\widetilde{s_{f}^{r^{\prime}}}\right)$ of linguistic variables are given in Table 3.

Table 3. The evalutions of DMs

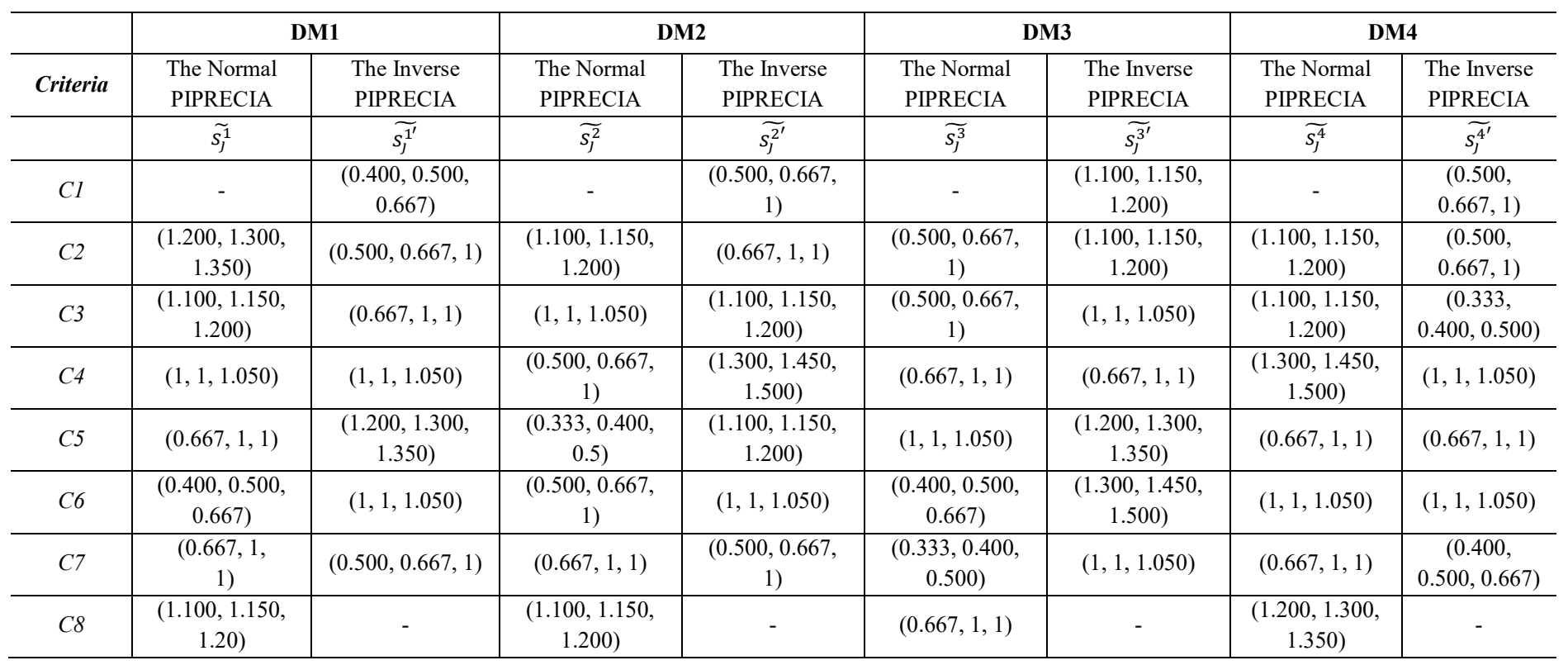

Subsequently, the evaluations of the DMs were aggregated with the arithmetic average to apply the remaining steps of the normal fuzzy PIPRECIA method. Calculated $\widetilde{k_{J}}, \widetilde{q_{J}}$, and $\widetilde{w_{J}}$ values from Eq. (2)-(4) are given in Table 4, respectively. The $\widetilde{w_{J}}$ are relative fuzzy weights computed by the normal fuzzy PIPRECIA steps.

These steps were also followed for the inverse fuzzy PIPRECIA. The $\widetilde{k^{\prime}}{ }_{j} \widetilde{q^{\prime}}$, and $\widetilde{w^{\prime}}{ }_{j}$ values from Eq. (6)-(8) are given in Table 5 , respectively. The $\widetilde{w^{\prime}}{ }_{j}$ are relative fuzzy weights computed by the inverse fuzzy PIPRECIA steps.
Table 4. Results of calculation in the normal fuzzy PIPRECIA

\begin{tabular}{c|c|c|c|c}
\hline Criteria & $\widetilde{s_{J}}$ & $\widetilde{k_{J}}$ & $\widetilde{q_{J}}$ & $\widetilde{w_{J}}$ \\
\hline \multirow{2}{*}{$C 1$} & - & $(1,1,1)$ & $(1,1,1)$ & $\begin{array}{c}0.096,0.138, \\
0.188)\end{array}$ \\
\hline \multirow{2}{*}{$C 2$} & $(0.975,1.067$, & $(0.813,0.933$, & $(0.976,1.072$, & $(0.094,0.148$, \\
& $1.188)$ & $1.025)$ & $1.231)$ & $0.232)$ \\
\hline \multirow{2}{*}{ C3 } & $(0.925,0.992$, & $(0.888,1.008$, & $(0.908,1.063$, & $(0.087,0.147$, \\
& $1.113)$ & $1.075)$ & $1.387)$ & $0.261)$ \\
\hline \multirow{2}{*}{ C4 } & $(0.867,1.029$, & $(0.863,0.971$, & $(0.801,1.095$, & $(0.077,0.151$, \\
& $1.138)$ & $1.133)$ & $1.608)$ & $0.303)$ \\
\hline \multirow{2}{*}{ C5 } & $(0.667,0.850$, & $(1.113,1.150$, & $(0.601,0.952$, & $(0.058,0.131$, \\
& $0.888)$ & $1.333)$ & $1.445)$ & $0.272)$ \\
\hline \multirow{2}{*}{ C6 } & $(0.575,0.667$, & $(1.154,1.333$, & $(0.422,0.714$, & $(0.041,0.099$, \\
& $0.846)$ & $1.425)$ & $1.252)$ & $0.236)$ \\
\hline \multirow{2}{*}{ C7 } & $(0.584,0.850$, & $(1.125,1.150$, & $(0.298,0.621$, & $(0.029,0.086$, \\
& $0.875)$ & $1.417)$ & $1.113)$ & $0.210)$ \\
\hline \multirow{2}{*}{ C8 } & $(1.017,1.150$, & $(0.813,0.850$, & $(0.303,0.730$, & $(0.029,0.101$, \\
& $1.188)$ & $0.983)$ & $1.370)$ & $0.258)$ \\
\hline \multirow{2}{*}{ Total } & & & $(5.306,7.246$, & \\
\hline
\end{tabular}


Table 5. Results of calculation in the inverse fuzzy PIPRECIA

\begin{tabular}{|c|c|c|c|c|}
\hline Criteria & $\widetilde{s_{J}}$ & $\widetilde{k_{j}}$ & $\widetilde{q_{J}}$ & $\widetilde{w^{\prime}}{ }_{j}$ \\
\hline $\mathrm{Cl}$ & $\begin{array}{c}0.625,0.746 \\
0.967)\end{array}$ & $\begin{array}{c}1.033,1.254 \\
1.375)\end{array}$ & $\begin{array}{c}0.363,0.768 \\
1.623)\end{array}$ & $\begin{array}{c}(0.033,0.099, \\
0.290)\end{array}$ \\
\hline$C 2$ & $\begin{array}{c}(0.692,0.871 \\
1.050)\end{array}$ & $\begin{array}{c}(0.950,1.129 \\
1.308)\end{array}$ & $\begin{array}{c}(0.499,0.963 \\
1.677)\end{array}$ & $\begin{array}{c}(0.045,0.124 \\
0.299)\end{array}$ \\
\hline C3 & $\begin{array}{c}0.775,0.888 \\
0.938)\end{array}$ & $\begin{array}{c}(1.063,1.113, \\
1.225)\end{array}$ & $\begin{array}{c}(0.652,1.088 \\
1.593)\end{array}$ & $\begin{array}{c}(0.059,0.140 \\
0.284)\end{array}$ \\
\hline C4 & $\begin{array}{c}0.992,1.113, \\
1.150)\end{array}$ & $\begin{array}{c}0.850,0.888 \\
1.008)\end{array}$ & $\begin{array}{c}(0.799,1.210, \\
1.693)\end{array}$ & $\begin{array}{c}(0.072,0.156, \\
0.302)\end{array}$ \\
\hline$C 5$ & $\begin{array}{c}(1.042,1.188, \\
1.225) \\
\end{array}$ & $\begin{array}{c}(0.775,0.813 \\
0.958) \\
\end{array}$ & $\begin{array}{c}(0.806,1.074 \\
1.439) \\
\end{array}$ & $\begin{array}{c}(0.073,0.139, \\
0.257) \\
\end{array}$ \\
\hline C6 & $\begin{array}{c}(1.075,1.113, \\
1.163)\end{array}$ & $\begin{array}{c}(0.838,0.888 \\
0.925)\end{array}$ & $\begin{array}{c}(0.772,0.872 \\
1.115)\end{array}$ & $\begin{array}{c}(0.070,0.113, \\
0.199)\end{array}$ \\
\hline$C 7$ & $\begin{array}{c}0.600,0.709, \\
0.929)\end{array}$ & $\begin{array}{c}(1.071,1.292, \\
1.400)\end{array}$ & $\begin{array}{c}(0.714,0.774, \\
0.934)\end{array}$ & $\begin{array}{c}(0.065,0.100, \\
0.167)\end{array}$ \\
\hline C8 & - & $(1,1,1)$ & $(1,1,1)$ & $\begin{array}{c}(0.090,0.129 \\
0.178)\end{array}$ \\
\hline Total & & & $\begin{array}{c}(5.605,7.749, \\
11.074)\end{array}$ & \\
\hline
\end{tabular}

The relative fuzzy weights $\widetilde{w_{J}}$ and $\widetilde{w^{\prime}}$ c calculated in Table 4 and Table 5 were combined using Eq. (9). The fuzzy weights of the criteria were defuzzified using Eq. (10) and the final criteria weights as crisp numbers $\left(w^{f}\right)$ were calculated in Table 6.

Table 6. The final weights of criteria

\begin{tabular}{c|c|c}
\hline Criteria & $\widetilde{w^{f}}{ }_{j}$ & ${ }^{f}{ }_{j}$ \\
\hline$C 1$ & $(0.064,0.119,0.239)$ & $\mathbf{0 . 1 3 0}$ \\
\hline$C 2$ & $(0.069,0.136,0.266)$ & $\mathbf{0 . 1 4 7}$ \\
\hline$C 3$ & $(0.073,0.143,0.273)$ & $\mathbf{0 . 1 5 3}$ \\
\hline$C 4$ & $(0.075,0.154,0.302)$ & $\mathbf{0 . 1 6 5}$ \\
\hline$C 5$ & $(0.065,0.135,0.265)$ & $\mathbf{0 . 1 4 5}$ \\
\hline$C 6$ & $(0.055,0.106,0.217)$ & $\mathbf{0 . 1 1 6}$ \\
\hline$C 7$ & $(0.047,0.093,0.188)$ & $\mathbf{0 . 1 0 1}$ \\
\hline$C 8$ & $(0.060,0.115,0.218)$ & $\mathbf{0 . 1 2 3}$ \\
\hline
\end{tabular}

According to the results, it was concluded that the most important criterion is $\mathrm{C} 4$ (distance to residential areas) with 0.165 . This criterion is followed by C3 (capacity) and C2 (accessibility to main roads), respectively. The result of the method revealed that the least important criterion is $\mathrm{C} 7$ (slope).

\section{Conclusion}

The COVID-19 virus continues to occupy the world agenda. It is recommended to use various medical products to protect against the virus. This situation creates an increase in the use of medical products and a subsequent medical waste burden. Medical waste management has become an important issue to handle. These waste products should be collected at certain sites before the disposal process. Site selection is a challenging problem due to the large number of attributes to consider. The importance of these attributes (criteria) directly affects the selection. MCDM methods are suitable tools for calculating criteria weights.

In this study, the factors affecting the selection of sites where medical wastes collect temporarily in Turkey were examined. In order to determine the evaluation criteria, a literature review was conducted and eight criteria were selected. Weights were calculated using the fuzzy PIPRECIA as an MCDM method with the opinions of four DMs. According to the results, the most important selection criterion was the distance to residential areas. Capacity and accessibility to main roads criteria are also criteria of high importance.

There are some limitations of this study. Since the fuzzy PIPRECIA method is a subjective method, the results are completely dependent on the opinions of the DMs. Different results may occur with groups of DMs made up of different people. In addition, the site assessment problems for medical waste may differ according to the economic, social, or geographical characteristics of different cities or countries over time as these are dynamic problems.

In future studies, it is recommended to reflect a more comprehensive perspective by increasing the number of DMs. The case study can be expanded by adding other economic, environmental, and social criteria. It would be beneficial to improve results by evaluating alternative sites with a hybrid MCDM method according to criteria weighted by fuzzy PIPRECIA.

\section{Acknowledge}

The author has declared no conflicts of interest.

\section{References}

Blagojević, A., Stević, Ž., Marinković, D., Kasalica, S., \& Rajilić, S. (2020). A novel entropy-fuzzy PIPRECIA-DEA model for safety evaluation of railway traffic. Symmetry, 12(9), 1479. doi: 10.3390/sym12091479

Boyacı, A. Ç., \& Şişman, A. (2021). Pandemic hospital site selection: a GIS-based MCDM approach employing Pythagorean fuzzy sets. Environmental Science and Pollution Research, 1-13. doi: 10.1007/s11356-021-15703-7

Chen, C. R., Huang, C. C., \& Tsuei, H. J. (2014). A hybrid MCDM model for improving GIS-based solar farms site selection. International Journal of Photoenergy, 2014. doi: $10.1155 / 2014 / 925370$

Crespo, C., Ibarz, G., Sáenz, C., Gonzalez, P., \& Roche, S. (2021). Study of Recycling Potential of FFP2 Face Masks and Characterization of the Plastic Mix-Material Obtained. A Way of Reducing Waste in Times of Covid-19. Waste and Biomass Valorization, 1-10. https://doi.org/10.1007/s12649-02101476-0

Çakır, E. (2021). Küresel bulanık kümeler ile güvenilirlik analizi. Mühendislik Bilimleri ve Tasarım Dergisi, 9(1), 230-239. doi: 10.21923/jesd.764492d

Çakır, E., Taş, M. A., \& Ulukan, Z. Spherical bipolar fuzzy weighted multi-facility location modeling for mobile COVID-19 vaccination clinics. Journal of Intelligent \& Fuzzy Systems, (Preprint), 1-14. doi: 10.3233/JIFS-219189

Đalić, I., Stević, Ž., Karamasa, C., \& Puška, A. (2020). A novel integrated fuzzy PIPRECIA-interval rough SAW model: Green supplier selection. Decision Making: Applications in Management and Engineering, 3(1), 126-145. doi: 10.31181/dmame2003114d

Hanine, M., Boutkhoum, O., Tikniouine, A., \& Agouti, T. (2016). Comparison of fuzzy AHP and fuzzy TODIM methods for landfill location selection. SpringerPlus, 5(1), 1-30. doi: 10.1186/s40064-016-2131-7 
Isalou, A. A., Zamani, V., Shahmoradi, B., \& Alizadeh, H. (2013). Landfill site selection using integrated fuzzy logic and analytic network process (F-ANP). Environmental Earth Sciences, 68(6), 1745-1755. doi: 10.1007/s12665-012-1865$\mathrm{y}$

Kahraman, C., Keshavarz Ghorabaee, M., Zavadskas, E. K., Cevik Onar, S., Yazdani, M., \& Oztaysi, B. (2017). Intuitionistic fuzzy EDAS method: an application to solid waste disposal site selection. Journal of Environmental Engineering and Landscape Management, 25(1), 1-12. doi: 10.3846/16486897.2017.1281139

Keršuliene, V., Zavadskas, E. K., \& Turskis, Z. (2010). Selection of rational dispute resolution method by applying new stepwise weight assessment ratio analysis (SWARA). Journal of business economics and management, 11(2), 243-258. doi: 10.3846/jbem. 2010.12

Kutlu Gündoğdu, F., \& Kahraman, C. (2019). A novel VIKOR method using spherical fuzzy sets and its application to warehouse site selection. Journal of Intelligent \& Fuzzy Systems, 37(1), 1197-1211. doi: 10.3233/JIFS-182651

Lin, M., Huang, C., \& Xu, Z. (2020). MULTIMOORA based MCDM model for site selection of car sharing station under picture fuzzy environment. Sustainable cities and society, 53, 101873. doi: 10.1016/j.scs.2019.101873

Liu, H. C., You, J. X., Fan, X. J., \& Chen, Y. Z. (2014). Site selection in waste management by the VIKOR method using linguistic assessment. Applied Soft Computing, 21, 453-461. doi: 10.1016/j.asoc.2014.04.004

Malemnganbi, R., \& Shimray, B. A. (2020). Solar Power Plant Site Selection: A Systematic Literature Review on MCDM Techniques Used. Electronic Systems and Intelligent Computing, 37-48. doi: 10.1007/978-981-15-7031-5_5

Mihajlović, J., Rajković, P., Petrović, G., \& Ćirić, D. (2019). The selection of the logistics distribution center location based on MCDM methodology in southern and eastern region in Serbia. Operational Research in Engineering Sciences: Theory and Applications, 2(2), 72-85. doi: 10.31181/oresta190247m

Moghaddas, N. H., \& Namaghi, H. H. (2011). Hazardous waste landfill site selection in Khorasan Razavi province, northeastern Iran. Arabian journal of geosciences, 4(1), 103113. doi: 10.1007/s12517-009-0083-8

Rahimi, S., Hafezalkotob, A., Monavari, S. M., Hafezalkotob, A., \& Rahimi, R. (2020). Sustainable landfill site selection for municipal solid waste based on a hybrid decision-making approach: Fuzzy group BWM-MULTIMOORA-GIS. Journal of Cleaner Production, 248, 119186. doi: 10.1016/j.jclepro.2019.119186

Sánchez-Lozano, J. M., Teruel-Solano, J., Soto-Elvira, P. L., \& García-Cascales, M. S. (2013). Geographical Information Systems (GIS) and Multi-Criteria Decision Making (MCDM) methods for the evaluation of solar farms locations: Case study in south-eastern Spain. Renewable and sustainable energy reviews, 24, 544-556. doi: 10.1016/j.rser.2013.03.019

Sangkham, S. (2020). Face mask and medical waste disposal during the novel COVID-19 pandemic in Asia. Case Studies in Chemical and Environmental Engineering, 2, 100052. https://doi.org/10.1016/j.cscee.2020.100052

Senvar, O., Otay, I., \& Bolturk, E. (2016). Hospital site selection via hesitant fuzzy TOPSIS. IFAC-PapersOnLine, 49(12), 1140-1145. doi: 10.1016/j.ifacol.2016.07.656

Shao, M., Han, Z., Sun, J., Xiao, C., Zhang, S., \& Zhao, Y. (2020). A review of multi-criteria decision making applications for renewable energy site selection. Renewable Energy, 157, 377-403. doi: 10.1016/j.renene.2020.04.137

Sharifi, M. A., \& Retsios, V. (2004). Site selection for waste disposal through spatial multiple criteria decision analysis. Journal of telecommunications and information technology, 28-38.

Sharma, H. B., Vanapalli, K. R., Cheela, V. S., Ranjan, V. P., Jaglan, A. K., Dubey, B., ... \& Bhattacharya, J. (2020). Challenges, opportunities, and innovations for effective solid waste management during and post COVID-19 pandemic. Resources, Conservation and Recycling, 162, 105052. doi: 10.1016/j.resconrec.2020.105052

Shereen, M. A., Khan, S., Kazmi, A., Bashir, N., \& Siddique, R. (2020). COVID-19 infection: Origin, transmission, and characteristics of human coronaviruses. Journal of advanced research, 24, 91. https://doi.org/ 10.1016/j.jare.2020.03.005

Shi, Q., Ren, H., Ma, X., \& Xiao, Y. (2019). Site selection of construction waste recycling plant. Journal of cleaner production, 227, 532-542. doi: 10.1016/j.jclepro.2019.04.252

South China Morning Post (SCMP) (2020). Coronavirus leaves China with mountains of medical waste. Accessed on: 10.07.2021.

https://www.scmp.com/news/china/society/article/3074722/c oronavirus-leaves-china-mountains-medical-waste

Stanujkic, D., Zavadskas, E. K., Karabasevic, D., Smarandache, F., \& Turskis, Z. (2017). The use of the pivot pairwise relative criteria importance assessment method for determining the weights of criteria. Romanian Journal of Economic Forecasting, 20, 116-133.

Stević, Ž., Stjepanović, Ž., Božičković, Z., Das, D. K., \& Stanujkić, D. (2018). Assessment of conditions for implementing information technology in a warehouse system: A novel fuzzy piprecia method. Symmetry, 10(11), 586. doi: 10.3390/sym10110586

Şener, Ş., Sener, E., \& Karagüzel, R. (2011). Solid waste disposal site selection with GIS and AHP methodology: a case study in Senirkent-Uluborlu (Isparta) Basin, Turkey. Environmental monitoring and assessment, 173(1), 533-554. doi: 10.1007/s10661-010-1403-x

Taş, M. A. \& Çakır, E., (2021). Green Supplier Selection Using Game Theory Based on Fuzzy SWARA. Sakarya University Journal of Science (Preprint), 1-14. doi: 10.16984/saufenbilder.877919

Tomašević, M., Lapuh, L., Stević, Ž., Stanujkić, D., \& Karabašević, D. (2020). Evaluation of criteria for the implementation of high-performance computing (HPC) in Danube Region countries using fuzzy PIPRECIA method. Sustainability, 12(7), 3017. doi: 10.3390/su12073017

Torkayesh, A. E., Zolfani, S. H., Kahvand, M., \& Khazaelpour, P. (2021). Landfill location selection for healthcare waste of urban areas using hybrid BWM-grey MARCOS model based on GIS. Sustainable Cities and Society, 67, 102712. 10.1016/j.scs.2021.102712

Tseng, M. L. (2011). Using a hybrid MCDM model to evaluate firm environmental knowledge management in uncertainty. Applied Soft Computing, 11(1), 1340-1352. doi: 10.1016/j.asoc.2010.04.006

U. S. Food \& Drug Administration (FDA) (2020). Q\&A for Consumers | Hand Sanitizers and COVID-19. Accessed on: 15.07.2021. https://www.fda.gov/drugs/information-drugclass/qa-consumers-hand-sanitizers-and-covid-19

Vahidnia, M. H., Alesheikh, A. A., \& Alimohammadi, A. (2009). Hospital site selection using fuzzy AHP and its derivatives. 
Journal of environmental management, 90(10), 3048-3056. doi: 10.1016/j.jenvman.2009.04.010

Vesković, S., Milinković, S., Abramović, B., \& Ljubaj, I. (2020). Determining criteria significance in selecting reach stackers by applying the fuzzy PIPRECIA method. Operational Research in Engineering Sciences: Theory and Applications, 3(1), 72-88. doi: 10.31181/oresta2001072v

World Health Organization (WHO) (2021). COVID-19 advice for the public: Getting vaccinated. Accessed on: 01.08.2021 https://www.who.int/emergencies/diseases/novelcoronavirus-2019/covid-19-vaccines/advice

Zadeh, L. A. (1965). Fuzzy Sets. Information and Control, 8(3), 338-353. doi: 10.1016/S0019-9958(65)90241-X

Żak, J., \& Węgliński, S. (2014). The selection of the logistics center location based on MCDM/A methodology. Transportation Research Procedia, 3, 555-564. doi: 10.1016/j.trpro.2014.10.034 